\title{
POTENSI TERAPI TUNGGAL ANTIMALARIA EKSTRAK ETANOL AKAR WIDURI (Calotropis gigantea) SECARA IN VIVO
}

\author{
Fiisyatirodiyah $^{1}$, Abdul Hakim², Roihatul Muti'ah², Elok Kamilah Hayati ${ }^{1}$ \\ ${ }^{1} J u r u s a n$ Kimia, Fakultas Sains dan Teknologi, Universitas Islam Negeri Maulana Malik \\ Ibrahim Malang, Malang Indonesia \\ 2Jurusan Farmasi, Fakultas Sains dan Teknologi, Universitas Islam Negeri Maulana \\ Malik Ibrahim Malang, Malang Indonesia
}

\begin{abstract}
ABSTRAK
Tanaman Widuri mengandung beberapa golongan senyawa aktif, diantaranya flavonoid, alkaloid, terpenoid dan steroid. Senyawa-senyawa tersebut telah terbukti bermanfaat sebagai antimalaria. Selain itu, daun Calotropis procera berpotensi antimalaria, sehingga diduga akar Calotropis gigantea juga berpotensi sebagai antimalaria karena mempunyai kekerabatan dalam satu genus. Penelitian ini bertujuan untuk mengetahui efektivitas antimalaria ekstrak etanol $80 \%$ akar Widuri (Calotropis gigantea) pada mencit terinfeksi Plasmodium berghei dan identifikasi golongan senyawa aktifnya.

Tahapan penelitian ini meliputi analisis kadar air sampel basah, preparasi sampel, analisis kadar air sampel kering, kemudian ekstraksi senyawa aktif dengan maserasi. Setelah itu, dilakukan uji antimalaria dan dilanjutkan dengan uji fitokimia. Senyawa aktif yang positif terhadap uji fitokimia diidentifikasi dengan metode Kromatografi Lapis Tipis.

Hasil kadar air sampel basah sebesar $51,17 \%$, sedangkan kadar air sampel keringnya sebesar $4,96 \%$. Isolasi senyawa aktif dilakukan dengan metode maserasi menggunakan pelarut etanol $80 \%$. Efektivitas antimalaria ekstrak etanol $80 \%$ akar tanaman Widuri (Calotropis gigantea) dalam menghambat pertumbuhan Plasmodium berghei pada mencit adalah sangat baik dengan nilai $\mathrm{ED}_{50}$ sebesar $4,26 \mathrm{mg} / \mathrm{Kg} \mathrm{BB}$. Golongan senyawa aktif yang terkandung dalam ekstrak etanol $80 \%$ akar Widuri (Calotropis gigantea) berdasarkan uji reagen adalah golongan senyawa terpenoid dan saponin. Hasil identifikasi menggunakan Kromatografi Lapis Tipis menunjukkan bahwa eluen terbaik untuk golongan senyawa terpenoid adalah $n$-heksana : etil asetat $(2: 8)$ yang menghasilkan penampakan warna ungu pada panjang gelombang $366 \mathrm{~nm}$ dengan pereaksi Lieberman-Burchard, sedangkan eluen terbaik untuk saponin adalah kloroform : aseton (4:1) dengan penampakan warna ungu pada panjang gelombang $366 \mathrm{~nm}$ dengan pereaksi $\mathrm{H}_{2} \mathrm{SO}_{4} 0,1 \mathrm{M}$.
\end{abstract}

Kata kunci : Calotropis gigantea, antimalarial, Fitokimia, Kromatografi Lapis Tipis

\section{PENDAHULUAN}

Malaria adalah penyakit infeksi yang paling luas penyebarannya di dunia dan diperkirakan 1/3 penduduk di dunia terkena penyakit infeksi. Malaria sampai saat ini masih merupakan masalah kesehatan dunia, khususnya di daerah tropis seperti di Indonesia.
Pada tahun 1997 sebanyak 93.7 juta penduduk Indonesia terancam terkena penyakit malaria (WHO, 2001). Penyebab penyakit ini adalah parasit Plasmodium yang termasuk protozoa (protista mirip hewan). Plasmodium merupakan golongan sporozoa yang membutuhkan vektor berupa nyamuk 
Anopheles. Ada empat spesies Plasmodium, yaitu Plasmodium vivax, Plasmodium ovale, Plasmodium falciparum dan Plasmodium malariae (Widjajanti, 1988).

Salah satu faktor utama penyebab peningkatan infeksi tersebut adalah timbulnya strain resisten terhadap obat malaria yang tersedia. Permasalahan resistensi terhadap obat malaria semakin lama semakin bertambah. Di wilayah Amazon dan Asia Tenggara telah ditemukan bahwa Plasmodium falciparum telah resisten terhadap klorokuin. Plasmodium vivax juga ditemukan telah resisten klorokuin di wilayah Papua Nugini, Papua Barat dan Sumatera (Widoyono, 2010).

Pemanfaatan tumbuhan sebagai obat tradisional diharapkan dapat menjadi salah satu alternatif dalam mengatasi penyakit malaria. Pada peneltian ini akan diuji efektivitas antimalaria dari akar tanaman Widuri (Calotropis gigantea).

Uji fitokimia pada akar Widuri (Calotropis gigantea) mengandung alkaloid, karbohidrat, glikosida, senyawa fenolik/tanin, flavonoid, saponin, sterol, protein dan asam amino dan senyawa-senyawa asam serta resin (Kumar et al., 2013). Penelitian yang dilakukan Ravi et al. (2011), menunjukkan aktivitas sitotoksik dari ekstrak etanol akar Calotropis gigantea dengan konsentrasi yang berbeda menggunakan metode BSLT diperoleh nilai $\mathrm{LC}_{50}$ sebesar 62,12 $\mu \mathrm{g} / \mathrm{mL}$.

Terdapat aktivitas antimalaria secara in vitro pada ekstrak daun Calotropis procera menggunakan variasi pelarut etanol, n-heksana, kloroform, metanol, etil asetat dan air. Pada penelitian tersebut menunjukkkan adanya penurunan aktivitas plasmodia seiring bertambahnya konsentrasi ekstrak daun Calotropis procera (Mudi dan Bukar, 2011).

Calotropis gigantea dan Calotropis procera merupakan dua jenis tumbuhan yang berbeda spesies saja. Jika Calotropis procera berpotensi sebagai antimalaria, maka dimungkinkan juga bahwa Calotropis gigantea memiliki aktivitas yang sama. Hal ini didasarkan kekerabatannya dalam satu genus, maka tumbuhan tersebut dimungkinkan memiliki kandungan kimia yang relatif sama serta memiliki aktifitas yang mirip. Oleh karena itu perlu dilakukan kajian lebih lanjut untuk membuktikan aktifitas farmakologinya (Marianne, dkk., 2011).

Penelitian ini diharapkan dapat memberikan kontribusi di bidang pengobatan herbal dan digunakan sebagai alternatif pengobatan malaria yang mudah, murah, aman dan efektif.

\section{METODE PENELITIAN Bahan}

Bahan-bahan yang digunakan pada penelitian ini adalah akar tanaman widuri (Calotropis gigantea), etanol $80 \%$, reagen Dragendroff, Mayer, Lieberman-Burchard, metanol $50 \%$, logam $\mathrm{Mg}, \mathrm{HCl} 2 \%, \mathrm{HCl}$ pekat, kloroform, asam asetat anhidrat, aquades, larutan $\mathrm{FeCl}_{3} 1 \%, \mathrm{H}_{2} \mathrm{SO}_{4}$. pekat, $\mathrm{HCN} 1 \mathrm{~N}, \mathrm{n}$-heksana, aseton, etil asetat, asam asetat, $\mathrm{H}_{2} \mathrm{SO}_{4} 0,1 \mathrm{M}$, mencit putih jantan galur Balb/C, pakan mencit (pellet), darah jantung dari mencit donor yang terinfeksi parasit, EDTA, larutan Alsever's, gliserol $10 \%$, larutan PBS, buffer Giemsa, Giemsa fluka, metanol, klorokuin, larutan CMC$\mathrm{Na} 1 \%$.

\section{PROSEDUR PENELITIAN Preparasi Sampel}

Akar tanaman Widuri diambil sebanyak $2 \mathrm{Kg}$. Kemudian dicuci dan dikeringkan di udara terbuka, dipotong kecil-kecil. Selanjutnya, dikeringkan dengan oven pada suhu $30-37{ }^{\circ} \mathrm{C}$ selama $5-6$ jam. Setelah kering, akar tanaman Widuri diblender sampai terbentuk serbuk dan diayak dengan ukuran 60 mesh sehingga terbentuk serbuk yang homogen.

Ekstraksi Senyawa Aktif

Serbuk akar tanaman Widuri ditimbang sebanyak $100 \mathrm{~g}$ dan 
direndam dengan dengan pelarut etanol $80 \%$ selama 24 jam pada suhu kamar dengan pengocokan $120 \mathrm{rpm}$ selama 3 jam menggunakan shaker. Filtrat yang diperoleh dipekatkan dengan rotary evaporator sampai diperoleh ekstrak pekat. Ekstrak pekat tersebut dioven pada suhu $37^{\circ} \mathrm{C}$ untuk menghilangkan residu etanolnya. Kemudian ditimbang sampai diperoleh berat yang konstan.

\section{Uji Antimalaria}

Ekstrak akar Widuri diujikan secara in vivo pada hewan coba. Hewan coba yang digunakan adalah mencit jantan Mus musculus yang dinfeksikan Plasmodium berghei dan dikelompokkan menjadi 6 kelompok, yaitu kelompok non infeksi; kontrol negatif; kontrol positif (klorokuin dosis $5,71 \mathrm{mg} / \mathrm{KgBB}$ ); ekstrak akar widuri dengan dosis $0,1 \mathrm{mg} / \mathrm{KgBB}$; 1 $\mathrm{mg} / \mathrm{KgBB}$ dan $10 \mathrm{mg} / \mathrm{KgBB}$. Terapi dilakukan ketika derajat parasitemia setelah infeksi mencapai $1-5 \%$ yang dihitung sebagai hari ke-0. Terapi dilakukan setiap hari selama 4 hari. Pengamatan derajat parasitemia dilakukan setiap hari ke-0, hari ke-1, hari ke-2, hari ke-3 dan hari ke-4.

\section{Uji Fitokimia}

Uji fitokimia merupakan analisis kualitatif yang digunakan untuk mengetahui kandungan golongan senyawa aktif yang terdapat dalam suatu bahan. Uji fitokimia dalam penelitian ini meliputi uji flavonoid, alkaloid, terpenoid, tanin dan saponin. Hasil positif dari uji fitokimia, diidentifikasi lebih lanjut dengan mengggunakan Kromatografi Lapis Tipis (KLT).

\section{Pemisahan Senyawa Aktif dengan Kromatografi Lapis Tipis}

Proses identifikasi merujuk pada sumber literatur Harbone (1987) dan Sastrohamidjojo (1985). Ekstrak pekat akar Widuri sebanyak $1000 \mathrm{mg}$ dilarutkan dalam $1 \mathrm{~mL}$ etanol $80 \%$. Kemudian, dimasukkan campuran eluen ke dalam bejana pengembang dan ditutup bejana pengembang selama 1 jam untuk menjenuhkan uap eluennya.

Pemisahan dengan KLT ini digunakan plat silika gel $\mathrm{F}_{254}$. Plat silika diaktivasi terlebih dahulu dengan pemanasan dalam oven pada suhu 60 - $70{ }^{\circ} \mathrm{C}$ selama 10 menit. Masingmasing plat dipotong dengan ukuran $1 \times 10^{2} \mathrm{~cm}$. Ekstrak etanol akar Widuri (Calotropis gigantea) ditotolkan pada plat $\mathrm{KLT}$ pada jarak $\pm 1 \mathrm{~cm}$ dari tepi bawah plat menggunakan pipa kapiler. Kemudian dielusi dengan masingmasing fase gerak golongan senyawanya. Noda disemprot dengan pereaksi dan diperiksa dibawah sinar UV pada panjang gelombang $366 \mathrm{~nm}$. Kemudian diamati noda tersebut dan dihitung nilai $R_{f}$.

\section{Analisis Data}

Nilai efektivitas dosis $50 \% \quad\left(E D_{50}\right)$ dihitung berdasarkan analisa probit \% penghambatan parasit selama 4 hari dan ditunjukkan dengan analisis regresi linear dengan program Microsoft Office Excel. Persen penghambatan juga dianalisis menggunakan MINITAB 16 dengan ANOVA two way dan dilanjutkan dengan uji tukey.

\section{HASIL DAN PEMBAHASAN Preparasi Sampel}

Pengeringan sampel dilakukan terlindung dari sinar matahari dengan harapan tidak merusak kandungan senyawa metabolit sekunder yang terkandung dalam sampel (Goeswin, 2007). Kemudian, sampel diblender untuk memperkecil ukuran partikel sehingga diperoleh serbuk akar widuri. Sampel kering diayak dengan ukuran 60 mesh. Ukuran 60 mesh merupakan ukuran yang cukup efektif agar pelarut dapat mengabsorbsi seluruh bagian sel terutama dinding sel. Dinding sel tumbuhan terbuka pada ukuran serbuk 60 mesh, sehingga memudahkan meresapnya pelarut selama proses ekstraksi (Dewi, 2007).

\section{Ekstraksi Senyawa Aktif}


Ekstrak pekat yang diperoleh berwarna kuning kecoklatan sebesar 3,93 gr. Ekstrak ini digunakan untuk uji antimalaria secara in vivo pada mencit jantan, uji golongan senyawa aktif dengan reagen dan identifikasi golongan senyawa aktif menggunakan Kromatografi Lapis Tipis dengan variasi berbagai eluen.

Tabel 1. Rata-rata derajat parasitemia serta standar deviasi ekstrak etanol $80 \%$ akar Widuri

\begin{tabular}{|c|c|c|c|c|c|}
\hline Kelompok & \multicolumn{5}{|c|}{ Rerata derajat parasitemia (\%) \pm} \\
& Serlakuan & \multicolumn{5}{|c|}{ Standar Deviasi } \\
\cline { 2 - 6 } & $\begin{array}{c}\text { Hari } \\
\text { ke-0 }\end{array}$ & $\begin{array}{c}\text { Hari } \\
\text { ke-1 }\end{array}$ & $\begin{array}{c}\text { Hari } \\
\text { ke-2 }\end{array}$ & $\begin{array}{c}\text { Hari } \\
\text { ke-3 }\end{array}$ & $\begin{array}{c}\text { Hari } \\
\text { ke-4 }\end{array}$ \\
\hline Kontrol & 2,1 & 2,7 & $3,3 \pm$ & 3,7 & 4,3 \\
negatif & \pm & \pm & 0,30 & \pm & \pm \\
& 0,43 & 0,64 & & 0,42 & 0,73 \\
\hline Kontrol & 2,4 & 1,7 & $1,3 \pm$ & 1,2 & 1,0 \\
positif & \pm & \pm & 0,32 & \pm & \pm \\
& 1,40 & 0,60 & & 0,31 & 0,25 \\
\hline Dosis 1 & 1,8 & 2,5 & $1,8 \pm$ & 1,6 & 2,0 \\
& \pm & \pm & 0,22 & \pm & \pm \\
& 0,64 & 0,57 & 0,27 & 0,66 \\
\hline Dosis 2 & 2,1 & 2,0 & $1,9 \pm$ & 1,9 & 1,6 \\
& \pm & \pm & 0,59 & \pm & \pm \\
& 1,24 & 0,43 & 0,59 & 0,43 \\
\hline Dosis 3 & 1,9 & 2,0 & 1,7 & 1,9 & 1,5 \\
& \pm & \pm & $\pm 0,24$ & \pm & \pm \\
& 0,76 & 0,59 & 0,29 & 0,54 \\
\hline
\end{tabular}

Keterangan:

Kontrol negatif : pemberian pelarut CMC-Na $1 \%$ yang diinfeksi Plasmodium berghei.

Kontrol positif : kelompok perlakuan klorokuin dosis 5,71 $\mathrm{mg} / \mathrm{Kg} \mathrm{BB}$.

Dosis 1 : terapi ekstrak etanol $80 \%$ akar widuri dosis $0,1 \mathrm{mg} / \mathrm{Kg}$.

Dosis 2 : terapi ekstrak etanol $80 \%$ akar widuri dosis $1 \mathrm{mg} / \mathrm{Kg} \mathrm{BB}$.

Dosis 3 : terapi ekstrak etanol $80 \%$ akar widuri dosis $10 \mathrm{mg} / \mathrm{Kg} \mathrm{BB}$.
Terapi obat atau ekstrak dilakukan ketika derajat parasitemia telah mencapai $1-5 \%$ yang dihitung sebagai hari ke-0. Pemberian bahan uji dilakukan sekali sehari selama 4 hari berturut-turut karena obat malaria pemberiannya cukup sehari sekali dan dalam waktu empat hari sudah dapat menghambat pertumbuhan parasit secara efektif (Kusumawardhani, dkk., 2005).

Aktivitas antimalaria ditetapkan melalui pengukuran derajat parasitemia pada hari ke-0 sampai 4. Penentuan derajat parasitemia pada hari ke-0 bertujuan untuk menentukan derajat parasitemia semua mencit telah berada pada range sekitar $1-5 \%$ pada hari dilakukannya terapi. Pemeriksaan derajat parasitemia pada hari ke-1, sampai ke-4 bertujuan untuk mengetahui profil perkembangan parasit selama dilakukan terapi. Hasil pemeriksaan derajat parasitemia dari hari ke-0 hingga hari ke-4 dapat ditunjukkan pada Tabel 1.

Berdasarkan Tabel 1 rata-rata derajat parasitemia kelompok kontrol negatif semakin besar dengan bertambahnya hari terapi, sedangkan kelompok kontrol positif semakin kecil dengan bertambahnya hari terapi. Hal ini disebabkan oleh perbedaan perlakuan dari kedua kelompok tersebut. Kelompok kontrol positif diterapi menggunakan obat klorokuin, sedangkan kontrol negatif tidak. Kelompok dosis menunjukkan adanya perubahan fluktuatif. Hal ini disebabkan oleh perbedaan reaksi tubuh mencit terhadap infeksi yang berbeda-beda, seperti metabolisme dan sistem kekebalan tubuhnya.

Eritrosit yang terinfeksi parasit dimulai dengan merozoit yang masuk ke aliran darah dan menginfeksi eritrosit. Kemudian, merozoit akan mengalami perubahan morfologi menjadi tropozoit (Widoyono, 2010). Eritrosit yang terinfeksi parasit ditunjukkan oleh anak panah. 


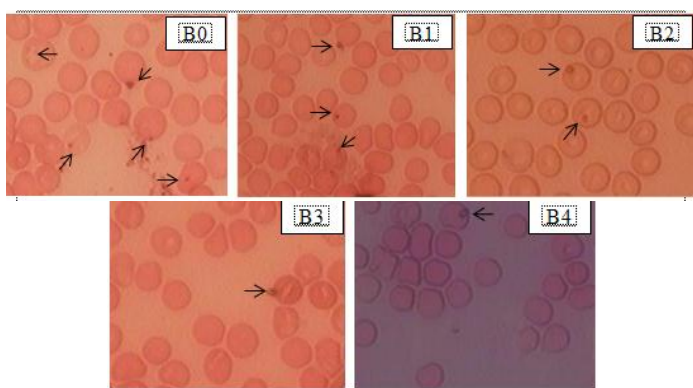

Gambar 1. Gambaran sel darah merah kontrol positif dengan pemberian klorokuin dosis $5,71 \mathrm{mg} / \mathrm{Kg}$ BB pada hari ke-0 sampai ke-4

Nilai derajat parasitemia yang digunakan adalah pada hari ke-4 atau hari terakhir pascaterapi. Setelah ditentukan derajat parasitemia masingmasing kelompok perlakuan, selanjutnya dihitung persen penghambatan parasit dengan menggunakan rumus berikut:

$\%$ penghambatan $=$

parasitemia kontrol negatif-parasitemia obat/ekstrak $x 100 \%$ parasitemia kontrol negatif

Prosentase

penghambatan pertumbuhan parasit dengan menggunakan rumus di atas pada hari ke-4 pascaterapi ditunjukkan pada Tabel 2.

Tabel 2. Persen penghambatan pertumbuhan parasit ekstrak etanol $80 \%$ akar Widuri pada hari ke-4

\begin{tabular}{|c|c|}
\hline $\begin{array}{c}\text { Dosis } \\
\text { (mg/Kg } \\
\text { BB) }\end{array}$ & $\begin{array}{c}\text { Persen } \\
\text { penghambatan } \\
\text { pertumbuhan parasit } \\
(\%)\end{array}$ \\
\hline 0,1 & 51,4 \\
\hline 1 & 61,7 \\
\hline 10 & 64,1 \\
\hline
\end{tabular}

Penentuan dosis efektif dalam menghambat $50 \%$ pertumbuhan parasit dengan menggunakan analisis probit \% penghambatan. Selanjutnya, dilakukan analisis regresi linier dengan menggunakan Microsoft Excel. Kurva yang diperoleh menghubungkan antara respon dengan dosis.

Pada kurva tersebut diperoleh persamaan garis liniernya, yaitu $\mathrm{y}=$ $0.175 x+5,24$. Nilai $E_{50}$ ekstrak etanol $80 \%$ akar Widuri kurang dari 10 $\mathrm{mg} / \mathrm{Kg}$ BB. Artinya, ekstrak etanol $80 \%$ akar Widuri dapat memiliki aktivitas antiplasmodial yang sangat bagus (Herintsoa, et al., 2010).

Tabel 3. Hasil uji fitokimia golongan senyawa aktif ekstrak etanol $80 \%$ akar Widuri

\begin{tabular}{|c|c|c|}
\hline No. & $\begin{array}{c}\text { Golongan } \\
\text { senyawa aktif }\end{array}$ & Hasil kualitatif \\
\hline 1. & Alkaloid & - \\
\hline 2. & Flavonoid & - \\
\hline 3. & Terpenoid & ++ \\
\hline 4. & Saponin & ++ \\
\hline 5. & Tanin & - \\
\hline
\end{tabular}

\section{Uji Fitokimia}

Uji fitokimia dilakukan untuk mengetahui kandungan golongan senyawa aktif yang terkandung pada ekstrak etanol $80 \%$ akar Widuri secara kualitatif. Hasil uji fitokimia golongan senyawa aktif ekstrak etanol $80 \%$ akar Widuri ditunjukkan pada Tabel 3.

Komponen aktif yang terdapat pada akar widuri adalah terpenoid dan saponin. Kandungan terpenoid ditunjukkan dengan terbentuknya cincin kecoklatan di antara dua pelarut yang tidak saling bercampur, sedangkan adanya senyawa saponin ditandai dengan adanya busa lagi yang tidak hilang selama 30 detik pada uji Forth.

\section{Pemisahan Senyawa Aktif dengan Kromatografi Lapis Tipis}

Sampel yang diidentifikasi dengan Kromatografi Lapis Tipis merupakan golongan senyawa aktif yang positif terhadap uji fitokimia.

\section{Terpenoid}

Eluen n-heksana : etil asetat (2 :

8) mampu memisahkan senyawa 
terpenoid yang terkandung dalam akar Widuri dengan sangat baik. Hal ini ditunjukkan dengan munculnya 5 noda yang tidak berekor. Penampakan noda pada panjang gelombang $366 \mathrm{~nm}$ adalah warna ungu. Hasil pemisahan dengan eluen $\mathrm{n}$-heksana : etil asetat (2 : 8) ditunjukkan pada Gambar 2.

Gambar

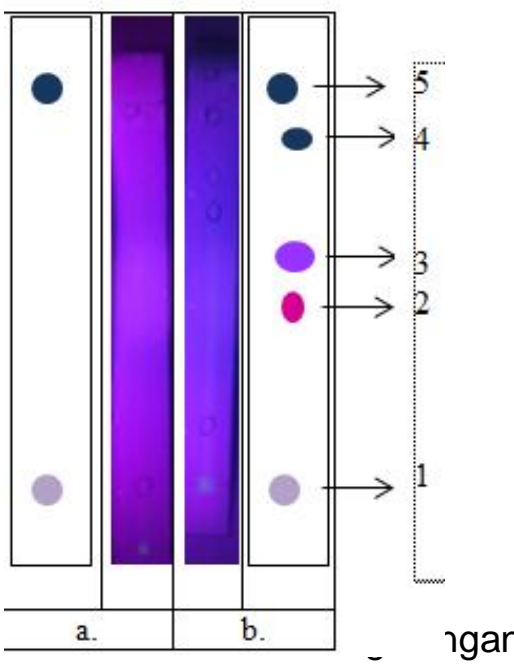

senyawa terpenoid eluen nheksana : etil asetat (2 : 8) dengan pereaksi LiebermannBurchard

Tabel 4. Hasil KLT senyawa terpenoid dengan eluen n-heksana:etil asetat $(2: 8)$

\begin{tabular}{|c|c|c|c|}
\hline $\begin{array}{c}\text { Noda } \\
\text { ke- }\end{array}$ & $\begin{array}{c}\text { Rf } \\
\text { Tiap } \\
\text { Noda }\end{array}$ & $\begin{array}{c}\text { Warna } \\
\text { noda } \\
\text { dengan } \\
\text { sinar UV } \\
\mathbf{3 6 6} \text { nm } \\
\text { sebelum } \\
\text { disemprot }\end{array}$ & $\begin{array}{c}\text { Warna } \\
\text { noda } \\
\text { dengan } \\
\text { sinar UV } \\
\mathbf{3 6 6} \mathbf{~ n m} \\
\text { setelah } \\
\text { disemprot }\end{array}$ \\
\hline 1 & 0,19 & $\begin{array}{c}\text { Ungu } \\
\text { muda }\end{array}$ & $\begin{array}{c}\text { Ungu } \\
\text { muda }\end{array}$ \\
\hline 2 & 0,68 & - & Ungu \\
\hline 3 & 0,76 & - & $\begin{array}{c}\text { Ungu } \\
\text { kebiruan }\end{array}$ \\
\hline 4 & 0,9 & - & Biru \\
\hline 5 & 0,99 & Biru & Biru \\
\hline
\end{tabular}

Identifikasi golongan terpenoid menggunakan KLT dengan eluen $\mathrm{n}$ heksana : etil asetat (2 : 8) menghasilkan penampakan warna ungu pada panjang gelombang $366 \mathrm{~nm}$ (Halimah, 2010).

Senyawa terpenoid diduga teridentifikasi pada $\mathrm{Rf} 0,19 ; 0,68 ; 0,76$ karena memiliki penampakan warna ungu pada panjang gelombang $366 \mathrm{~nm}$.

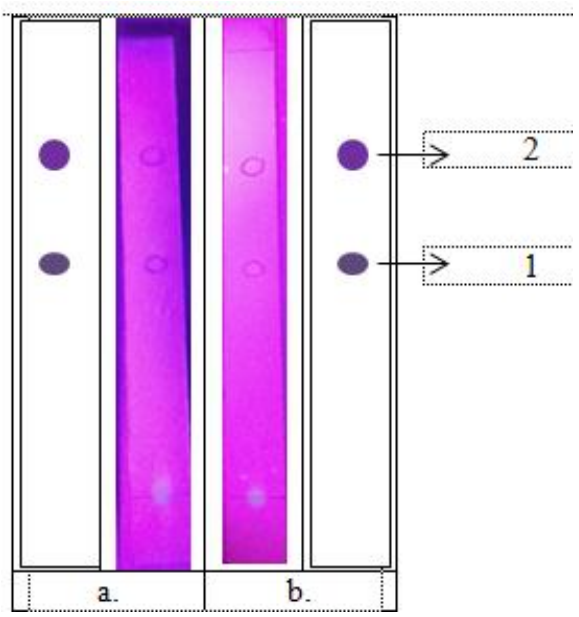

Gambar 3. Hasil KLT golongan senyawa saponin dengan eluen kloroform : aseton (4:1) dengan pereaksi $\mathrm{H}_{2} \mathrm{SO}_{4} 0,1 \mathrm{M}$

\section{Saponin}

Campuran eluen kloroform : aseton (4:1) menghasilkan 2 buah noda yang terpisah dengan sangat baik. Pola noda yang terbentuk berbentuk bundar dan tidak berekor. Penampakan noda pada panjang gelombang $366 \mathrm{~nm}$ adalah warna ungu. Hasil pemisahan dengan eluen kloroform : aseton (4:1) ditunjukkan pada Gambar 3.

Identifikasi saponin menggunakan Kromatografi Lapis Tipis dengan campuran eluen kloroform : aseton (4 : 1) menghasilkan nilai $\mathrm{Rf}$ sebesar 0,77 (Suryanti, 2005). Senyawa saponin diduga teridentifikasi pada kedua noda tersebut karena menunjukkan penampakan warna ungu pada panjang gelombang $366 \mathrm{~nm}$ seperti pada Tabel 5 . 
Tabel 5. Hasil KLT senyawa saponin dengan eluen kloroform : aseton $(4: 1)$

\begin{tabular}{|c|c|c|c|}
\hline $\begin{array}{c}\text { Noda } \\
\text { ke- }\end{array}$ & $\begin{array}{c}\text { Rf } \\
\text { Tiap } \\
\text { Noda }\end{array}$ & $\begin{array}{c}\text { Warna } \\
\text { noda } \\
\text { dengan } \\
\text { sinar UV } \\
\mathbf{3 6 6} \mathbf{~ n m} \\
\text { sebelum } \\
\text { disemprot }\end{array}$ & $\begin{array}{c}\text { Warna } \\
\text { noda } \\
\text { dengan } \\
\text { sinar UV } \\
\mathbf{3 6 6} \mathbf{~} \mathbf{m} \\
\text { setelah } \\
\text { disemprot }\end{array}$ \\
\hline 1 & 0,5 & $\begin{array}{c}\text { Ungu } \\
\text { muda }\end{array}$ & Ungu \\
\hline 2 & 0,75 & $\begin{array}{c}\text { Ungu } \\
\text { muda }\end{array}$ & Ungu \\
\hline
\end{tabular}

\section{KESIMPULAN}

Kesimpulan dari penelitian ini adalah efektivitas antimalaria ekstrak etanol $80 \%$ akar tanaman Widuri (Calotropis gigantea) dalam menghambat pertumbuhan Plasmodium berghei pada mencit secara in vivo adalah sangat baik dengan nilai $E D_{50}$ sebesar 4,26 $\mathrm{mg} / \mathrm{Kg}$ BB. Sedangkan golongan senyawa aktif yang terkandung dalam ekstrak etanol $80 \%$ akar Widuri (Calotropis gigantea) berdasarkan hasil identifikasi menggunakan uji reagen adalah golongan senyawa terpenoid dan saponin. Hasil identifikasi menggunakan Kromatografi Lapis Tipis menunjukkan bahwa eluen terbaik golongan senyawa terpenoid adalah nheksana : etil asetat (2 : 8) yang menghasilkan penampakan warna ungu pada panjang gelombang $366 \mathrm{~nm}$ dengan pereaksi Lieberman-Burchard, sedangkan eluen terbaik senyawa saponin dengan eluen terbaik kloroform : aseton $(4: 1)$ dengan penampakan warna ungu pada panjang gelombang $366 \mathrm{~nm}$ dengan pereaksi $\mathrm{H}_{2} \mathrm{SO}_{4} 0,1 \mathrm{M}$.

\section{DAFTAR PUSTAKA}

Dewi, K.L. 2007. Kajian Ekstrak Umbi Gadung (Dioscorea hispida), Biji Rerak (Sapindus rarak) dan Biji Sirsak (Annona muricata L.) Sebagai Bahan Pengawet Alami Kayu. Skripsi Diterbitkan. Bogor:
Fakultas Kehutana Institut Pertanian Bogor.

Goeswin, A. 2007. Teknologi Bahan Alam. Bandung: ITB Press

Halimah, N. 2010. Uji Fitokimia dan Uji Toksisitas Ekstrak Tanaman Anting-anting (Acalypa indica L.) Terhadap Larva Udang (Artemia salina Leach). Skripsi Tidak Diterbitkan. Malang: UIN Maulana Malik Ibrahim Malang

Harborne, J. B. 1996. Metode Fitokimia Penuntun Cara Modern Menganalisis Tumbuhan. Bandung: Penerbit ITB

Herintsoa, R., Robijaona RB, R.A.S., Rasoamahanina AM., R.E.K.F., Rakotoarimanana, H., Rakotondrabe. MH., Raminosoa, M., Rakotozafy, A., Ranaivoravo, J., Rajanoarison, JF., Ratsimamanga, S., Gatson, LT., Gauthier, KM., Solomon, D. dan Jacob, O.M. 2005. Screening of Plant Extracts for Searching Antiplasmodial Activity. $11^{\text {th }}$ Madagascar: NAPRECA Symposium Book of Proceedings, Antananarivo

Kumar, S.P., Suresh dan Kalvathy, S. 2013. Review on a Potential Herb Calotropis gigantea Linn. Annamalai University

Kusumawardhani, D., Widyawaruyanti, A. dan Kusumawati, I. 2005. Efek Antimalaria Ekstrak Sambiloto Terstandar (Parameter Kadar Aandrografolida) Pada Mencit Terinfeksi Plasmodium berghei. Majalah Farmasi Airlangga. Vol.5. No.1. Surabaya: Ilmu Bahan Alam Fakultas Farmasi Universitas Airlangga

Marianne, Y. dan Rosnani. 2011. Antidiabetic Activity From Ethanol Extract of Kluwih's Leaf (Artocarpus camansi). Jurnal Natural. Universitas Syiah Kuala, Darussalam, Banda Aceh

Mudi, S.Y. dan Bukar, A. 2011. Antiplasmodia Activity of Leaf Extracts of Calotropis procera 
Linn. Nigeria: Biochemistry Vol. 23, No. 1

Ravi, R.G., Harikesh D., Chandrasehar, T.R., Pramod, Y.G. dan Angad, P.M. 2011. Cytotoxic Activity of Ethanolic Root Extract of Calotropis gigantean Linn. International Journal of Drug Development and Research. Netherland

Sastrohamidjojo, H. 1985. Kromatografi. Yogyakarta: UGM Press

Suryanti, V., Martiana, S.M. dan Kristinawati, D. 2005. Komponen Kimia Buah Pare Belut (Trichosanthes anguina L.). Jurnal Alchemy. Volume 4, Nomor 2: 28-34

Widjajanti, N. 1998. Obat-obatan. Yogyakarta: Kanisius

Widoyono. 2010. Penyakit Tropis: Epidemologi, Penularan, Pencegahan dan Pemberantasannya Edisi Kedua. Jakarta: Erlangga 